\title{
Studies on hair production attribute in Indian dromedary camel managed in an organised farm
}

\author{
CHAMPAK BHAKAT ${ }^{\prime}$, S C MEHATA ${ }^{2}$ and M S SAHANI ${ }^{3}$ \\ National Research Centre on Camel, Jorbeer, Bikaner, Rajasthan 334001 India
}

Received: 6 August 2001; Accepted: 27 September 2001

Key word: Camel, Hair, Dromedary, Production

The camel hair and its products can be an important source of additional income for camel keepers. The camel hair is widely used in rural cottage industry of Rajasthan and Gujarat for preparation of various items (Sahani and Khanna 1993). The total world camel population is estimated to be 19.286 million of which India has third highest camel population of 1.52 million (FAO 1998) after Somalia and Sudan. The main body sites of hair coverage in the dromedary camels are shoulders, mid portion of body, neck and hump regions. Camel hair blends with wool, silk, waste and polyester have shown encouraging results (Gupta et al. 1987, 1989). Patni and Dhillon (1988) reported that it is worthwhile to blend camel hair with polyester, wool or silk waste. The camel hair are durable, strong and have low conductivity (Muksa 1981). A camel hair fabric of $620 \mathrm{~g}$ weight will be as warm as a pure wool fabric of $900 \mathrm{~g}$ weight (Khanna and Rai 1991). The present investigation was undertaken to evaluate the production potential of different breeds and to suggest suitable improvement strategies. Therefore, it is an attempt to explore the different factors influencing hair production attribute in Indian dromedary camel managed in an organised farm.

Annual hair production data from 590 camels (Camelus dromedarius) belonging to the National Research Centre on Camel, Bikaner, were recorded and analysed. The data on annual hair production from Bikaneri (265), Jaisalmeri (227) and Kachichhi (98) were recorded. All the camels were managed under semi-intensive system of management and were daily sent for grazing/browsing for about $6 \mathrm{hr}$ and offered dry fodder (@2\% of body weight) in evening after return from grazing. The camel belonged to different age groups, viz. 1 year (70), 2 years (62), 3 years (74), 4-6 years ( 110$)$, and above 6 years (274). Annual hair yield data from different year's, viz. 1998 - 1999 (159), 1999 - 2000 (204) and 2000 -2001 (227) were utilized. The hairs were sheared from all over body regions of camel by using hand machine during the last week of March of every year. The sheared hairs of individual animal were collected in polythene bags after

Present address: ${ }^{1.2}$ Scientist, ${ }^{3}$ Director. proper skirting (removal of dust and other vegetable matters). The individual camel hair weighted in $5 \mathrm{~kg}$ capacity balance with minimum division of $10 \mathrm{~g}$. The recorded data were classified according to breed, sex, age and year of production. The recorded and classified data were subjected to analysis by applying mixed mode least squares and maximum likelihood computer programme (Harvey 1987).

The Bikaneri breed of camel produced maximum annual hair yield, followed by Jaisalmeri and Kachchhi breed (Table 1). Similar trend in annual hair production was also reported by Sahani et al. (1996 and 1998). Yadav et al. (2000) reported that young Bikaneri camels indicated higher staple length compared to young Jaisalmeri and Kachchhi camel. Bikaneri camels produce more quantity of hair may be because of

Table 1. Breed and sex-wise least square mean \pm SE for anmual hair production $(\mathrm{g}$ ) of Indian dromedary camel

\begin{tabular}{lccc}
\hline Breed & Overall & \multicolumn{2}{c}{ Sex } \\
\cline { 3 - 4 } & & Male & Female \\
\hline Bikaneri & $933.85 \pm$ & $1014.08 \pm$ & $853.63 \pm$ \\
& 17.99 & 26.36 & $20.6 i$ \\
& $(265)$ & $(91)$ & $(174)$ \\
Jaisalmeri & $733.43 \pm$ & $771.28 \pm$ & $695.59 \pm$ \\
& 17.84 & 25.42 & 23.92 \\
& $(227)$ & $(97)$ & $(130)$ \\
Kachchhi & $623.22 \pm$ & $643.95 \pm$ & $602.50 \pm$ \\
& 25.97 & 39.91 & 32.90 \\
& $(98)$ & $(39)$ & $(59)$ \\
Overall & $763.50 \pm$ & $809.77 \pm$ & $717.24 \pm$ \\
& 12.72 & 18.20 & 16.45 \\
& $(590)$ & $(227)$ & $(363)$ \\
\hline
\end{tabular}

greater body size, and the staple length was also higher in this breed compared to other breeds. The male Bikaneri camels produced higher hair yield than females. Other breeds showed similar trend of observations. The 3 years age group produced higher quantity of hair, followed by 2 years, 4 to 6 
years, and lyear age group (Table 2). Above 6 years age group produced lowest quantity of hair yield. The present results are consistent with the observation reported by Sahani et al. (1998). The main reason behind this appears to be the protection provided by nature to the young animals. There was not much variation in annual hair production in different year. Almost sinilar trend of production was observed over

Table 2. Age- and year-wise least square mean $\pm \mathrm{SE}$ for annual hair production $(\mathrm{g})$ in indigenous camel

\begin{tabular}{lcc} 
Age group (year) & $\begin{array}{c}\text { Number of } \\
\text { observations }\end{array}$ & Mean \pm SE \\
1 & 70 & $630.68 \pm 30.39$ \\
2 & 62 & $879.50 \pm 31.85$ \\
3. & 74 & $1035.64 \pm 29.14$ \\
$4-6$ & 110 & $329.03 \pm 24.20$ \\
$>6$ & 274 & $542.67 \pm 16.95$ \\
Overal! & 590 & $763.50 \pm 12.72$ \\
Year of production & & \\
$1998-1999$ & 159 & $771.84 \pm 20.67$ \\
$1999-2000$ & 204 & $731.83 \pm 19.52$ \\
$2000-2001$ & 227 & $786.84 \pm 18.18$ \\
Overal! & 590 & $763.50 \pm 12.72$ \\
\hline
\end{tabular}

the years. The breed factor significantly $(P<0.01)$ affected the annual hair production. Bikaneri breed of camel significantly $(P<0.01)$ produced higher annual hair yield as compared to the other 2 genetic groups. As expected the sex of camel had a significant $(P<0.01)$ influence on annual hair yield. The male camels of all breeds produced significantly higher annual hair yield as compared to the female camels. Age of camel also significantly $(P<0.01)$ affected the annual hair yield. On the other hand year of production did not affect the annual hair yield significantly. The interaction between genetic group and sex was nonsignificant. The Indian dromedary camel breeds showed a wide colour variation ranging from light brown in Jaisalmeri breed to brown, dark brown and blackish colour in Bikaneri and Kachchhi breeds of camel. The skin coat of younger camels ( 1 to 3 years age) was more soft and finer compared to adult age group. The study can be concluded that camels of Bikaneri breed of 2.3 years of age produce higher annual hair yield as compared to other age groups and breeds. It shows enough variation in the annual hair production and hence there exists scope for future improvement in production. The potentiality of camel hair production indicated scope for preparation of blends of camel hair with other natural and synthetic fibres in addition to its traditional use under village conditions.

\section{SUMMARY}

In order to obtain optimum profit from camel rearing it is essential to study effective utilization of production of camel hair. Annual hair production of 590 dromedary camels belonging to 3 breeds that belonged to 5 different age groups were studied. The Bikaneri breed of camel produced maximum annual hair yield followed by Jaisalmeri and Kachchhi breed. The male camel produced heavier annual hair yield than female in all breeds. The highest annual hair production was at 3 year age group followed by 2,4 to 6,1 year and above 6 year age group.

\section{REFERENCES}

FAO. 1998. Production Year Book Rome. Italy.

Gupta N P, Pokharna A K, Arora R K and Sugunar S. 1987. Mechanical processing of ivool, speciality hair and their blends. Antual Report 1987, CSWRI, Avikanagar.

Gputa N P, Patni P C and Sugumar S. 1989. Propertics and processing of camel hair in India. Indian Textile Journal 99 (4): 180.

Harvey W. 1987. Mixed Model Least squares and Maximum Likelihood Computer Programme. United States, Department of Agriculture, New York.

Khanna N D and Rai A K. 1990. Scientific camel management can check desertification. Indian Farming 40 (9): 33-35.

Khanna N D and Rai A K. 1991. Camel rearing in the Indian arid zone. Annals of Arid Zone 30 (1): $1-10$.

Mukasa E. 1981. A Bibliographical Review. International Livestock Centre for Africa, P O box 5689, Addis Ababa, Ethiopia.

Patni P C and Dhillon R S. 1988. Areas and prospects of utilization of camel hair and hidc. National Seminar on Perceptions and potentials of camel research in India, 9-10 October 1988. NRCC, Bikaner.

Sahani M S and Khanna N D. 1993. The camel fibre and its prospective utility. National seminar on prodaction and utilization of animal fibres, Bikaner, 1993, December, 13-14.

Sahani M S, Sharma N and Khanna N D. 1996. Hair production in Indian camels (Camelis dromedarius) managed under farm condition. Indian Veterinary Joumal 73 (5): 531-33.

Sahani M S, Rathinasabapathy M, Rajendra K and Khanna N D 1998. Factors affecting annual hair production in indigenous breeds of camels (Camelus dromedarius) under farm condition. Indian Journal of Animal Sciences 68 (3): 267-68.

Yadav B, Mishra B P, Bhakat Champak and Sahani M S. 2000. Hair quality attributes of Camelus dromedarius. Indian Journal of Animal Sciences 70 (2): $211-12$. 